ISSN : 2337-3067

E-Jurnal Ekonomi dan Bisnis Universitas Udayana 7.4 (2018):1107-1134

\title{
PENGARUH KEPEMIMPINAN TERHADAP KINERJA KARYAWAN YANG DIMODERASI OLEH MOTIVASI KERJA PADA BPR SE-KECAMATAN SUKAWATI GIANYAR
}

\author{
I Komang Gede ${ }^{1}$ \\ Putu Saroyeni Piartini \\ ${ }^{1}$ Fakultas Ekonomi dan Bisnis Universitas Udayana (Unud), Bali, Indonesia \\ email: komanggede187@yahoo.com
}

\begin{abstract}
ABSTRAK
Kinerja dapat diketahui dan diukur jika individu atau sekelompok karyawan telah mempunyai kriteria atau standar keberhasilan tolak ukur yang telah ditetapkan oleh organisasi. Penelitian ini dilakukan di seluruh BPR (Bank Perkreditan Rakyat) se-Kecamatan Sukawati Gianyar yang bergerak dibidang perbankan. Jumlah sampel yakni dengan menggunakan metode slovin ialah sebanyak 68 responden. Hasil analisis dapat diketahui bahwa kepemimpinan berpengaruh positif dan signifikan terhadap kinerja karyawan. Motivasi kerja berpengaruh positif dan signifikan terhadap kinerja karyawan. Motivasi kerja memoderasi pengaruh kepemimpinan secara positif dan signifikan terhadap kinerja karyawan. Saran yang dapat diberikan, pimpinan BPR di Kabupaten Gianyar harus dengan jelas memberikan sikap yang dianggap baik oleh bawahan, berkompeten di dalam memberikan tugas, seperti kesesuaian tugas dengan kemampuan karyawan sehingga menghasilkan kinerja yang baik. Dalam memotivasi karyawan setiap pimpinan harus menanamkan sikap positif karyawan terhadap pekerjaan yang diterimanya, seperti sikap tanggung jawab dan mengajarkan agar segala pekerjaan yang diberikan segera diselesaikan untuk mencapai hasil yang baik sebagai motivasi karyawan dalam meningkatkan kinerja diperusahaan, sehingga karyawan memiliki kemampuan untuk mengatasi permasalahan yang dihadapinya untuk menunjukkan kinerja yang baik.
\end{abstract}

Kata kunci : kepemimpinan, motivasi kerja dan kinerja

\section{ABSTRACT}

Performance can be known and measured if an individual or group of employees has the criteria or standard of success of the benchmarks set by the organization. This research was conducted in all BPR (Bank Perkreditan Rakyat) in Sukawati District Gianyar which engaged in banking. The number of samples using slovin method is 68 respondents. Analysis results can be seen that leadership has a positive and significant impact on employee performance. Motivation of work has a positive and significant impact on employee performance. Work motivation moderates the influence of leadership positively and significantly on employee performance. Suggestions that can be given, the BPR leaders in Gianyar Regency should clearly provide the attitude that is considered good by subordinates, competent in providing tasks, such as the suitability of tasks with the ability of employees to produce good performance. In motivating employees every leader should instill positive attitude of employees to the work they receive, such as the attitude of responsibility and teach that all work given immediately be completed to achieve good results as employee motivation in improving the performance in the company, so that employees have the ability to overcome the problems it faces to show good performance.

Keywords: leadership, work motivation, performance 


\section{PENDAHULUAN}

Bank merupakan suatu lembaga yang mendapatkan izin untuk mengerahkan dana yang berasal dari masyarakat berupa simpanan dan menyalurkan dana tersebut kepada masyarakat yang berupa pinjaman, sehinggga bank berfungsi sebagai perantara antara penabung dan pemakai akhir, rumah tangga dan perusahaan.. Kurangnya komunikasi serta aneka ragam pengalaman berkenaan dengan likuiditas, risiko, waktu dan sebagainya, telah membuat hubungan langsung antara penabung dengan investor tidak efisien dan terbatas ruang lingkupnya (Ahmad, 2014).

Bank Perkreditan Rakyat yang biasa disingkat dengan BPR selalu melayani golongan pengusaha mikro, kecil dan menengah dengan lokasi pelayanan yang tidak melewati batas wilayah Kabupaten/Kota. Menghadapi persaingan di sektor perbankan yang semakin ketat, kepercayaan dari masyarakat merupakan salah satu kunci sukses yang mendorong kemajuan perusahaan (Dhammika, 2014). Sama seperti bank lainnya Bank Perkreditan juga harus diketahui kesehatannya. Kesehatannya bank dapat diartikan sebagai kemampuan suatu bank untuk melakukan kegiatan operasional perbankan secara normal dan mampu memenuhi semua kewajibannya dengan baik dengan cara-cara yang sesuai dengan peraturan perbankan yang berlaku (Marudut, 2014).

Sumber daya manusia dapat menentukan tingkat kinerja suatu bank selain analisa laporan keuangan BPR, sumber daya manusia yang disoroti pengembangannya dalam penelitian ini adalah sumber daya manusia karyawan BPR di Sukawati Gianyar, karena keberadaaanya sangat penting dalam memberikan 
peluang yang besar kepada masyarakat pedesaan untuk meningkatkan kesejahteraan hidupnya. Untuk menjamin kesinambungan perusahaan, perlu adanya perpaduan dari enam aspek faktor produksi (Fitria dan Djum, 2014) yaitu man, money, materials, methods, market, machine.

Beberapa penelitian menyimpulkan kinerja dalam menjalankan fungsinya tidak berdiri sendiri, tetapi berhubungan dengan peran kepemimpinan dan tingkat tingkat motivasi yang diberikan oleh perusahaan. Kepemimpinan merupakan kemampuan yang dimiliki seseorang untuk mempengaruhi orang-orang lain agar bekerja mencapai tujuan dan sasaran. Sehingga, sangat diperlukan teladan dari seorang pemimpin yang nantinya menjadi panutan bawahannya (Handoko dan Reksohadiprodjo, 2009:294).

Persaingan perbankan dan lembaga keuangan menyiratkan perlunya optimalisasi kinerja sumber daya manusianya pada Bank Perkreditan Rakyat (BPR) agar tetap bertahan. Dengan kata lain, untuk meningkatkan daya saing, maka berbagai macam faktor yang yang meningkatkan kinerja sumber daya manusianya perlu mendapat perhatian serius. Menurut Trotter (1986) dalam Sadia et al., (2015) mendefinisikan bahwa seorang yang kompeten adalah orang yang dengan keterampilannya mengerjakan pekerjaan yang mudah, cepat, intuitif dan sangat jarang atau tidak pernah membuat kesalahan. Ini menujukan bahwa karyawan harus memiliki kemampuan yang baik dalam menjalankan tugas-tugasnya agar hasil dari kinerja relevan dan handal. 
Fenomena menyangkut rendahnya kinerja yang terjadi pada saat ini melalui hasil wawancara pada beberapa karyawan di BPR Tish, BPR Sukawati Pancakanti, BPR Eka Ayu, BPR Suandana, BPR Sadhu Artha, BPR Artha Bali Jaya yang digunakan sebagai sampel awal, diketahui karyawan dengan pengalaman kerja yang lama, karyawan senior, sering kurang mau mengikuti pelatihan, karena merasa sudah mampu menyelesaikan pekerjaan yang menjadi tanggungjawabnya, terlihat bahwa ada beberapa karyawan senior dalam hal ini adalah mereka yang memiliki pengalaman kerja sudah lama dalam arti kata telah bekerja lebih dari 3 tahun memiliki kinerja yang standar, tidak terlalu bagus dan juga tidak terlalu buruk, hal ini dapat dipengaruhi karena posisi mereka pada saat ini sudah mapan dan juga merupakan karyawan tetap. Namun yang menjadi perhatian adalah sedikitnya karyawan dengan pengalaman kerja yang cukup mau mengikuti pelatihan. Karyawan senior sebagain besar memiliki anggapan bahwa pelatihan hanya diperlukan bagi karyawan baru dan bukan merupakan bagian dari rencana kerja perusahaan dalam peningkatan kinerja. Hal ini sudah dianggap menjadi kebiasaan sehingga akan berdampak dalam mengurangi kinerja perusahaan secara umum (Ahmad, 2014).

Bank Perkreditan Rakyat (BPR) merupakan lembaga keuangan bank yang menerima simpanan hanya dalam bentuk deposito berjangka, tabungan, dan bentuk lainnya yang dipersamakan dengan itu dan menyalurkan dana sebagai usaha BPR. BPR perlu memperhatikan aspek-aspek untuk menilai tingkat kesehatan bank antara lain capital, asset quality, management, earning, dan likuiditas. Aspek-aspek ini 
ditetapkan berdasarkan kesepakatan internasional seperti yang telah ditetapkan oleh Bank of International Settlement (BIS). Dengan menggunakan metode camel yang mengacu pada peraturan Bank Indonesia No.6/23/DPDM tanggal 24 Mei 2004 kepada semua Bank Umum dan BPR di Indonesia tentang penilaian kesehatan Bank.Sehat atau tidak sehatnya suatu koperasi bisa dilihat dari kreteria skor yang telah ditentukan, seperti pada Tabel 1.

\section{Tabel 1.}

\begin{tabular}{ccc} 
Rata-rata Produktivitas Kerja BPR dengan Predikat Sehat Se-Kecamatan \\
& \multicolumn{3}{c}{ Sukawati Kabupaten Gianyar, 2016 } \\
\hline Nama BPR & Rata-Rata Produktivitas & Nilai/Kategori \\
\hline BPR Tish & $85 \%$ & $81-100 /$ Sehat \\
BPR Ulati Dana Rahayu & $87 \%$ & $81-100 /$ Sehat \\
BPR Eka Ayu & $90 \%$ & $81-100 /$ Sehat \\
\hline
\end{tabular}

Sumber: Perbarindo Bali, 2017

Tabel 1. menunjukan pencapaian rata-rata produktivitas pada BPR Tish 85 persen, sehingga tergolong dalam predikat sehat, BPR Ulati Dana Rahayu mencapai 87 persen dengan predikat sehat untuk BPR Eka Ayu mencapai 90 persen dengan predikat sehat, hal ini menunjukan bahwa kinerja organisasi baik sehingga tercapainya target sesuai dengan ketentuan yang berlaku pada bank, pencapaian yang diperoleh tidak terlepas dari peran pemimpin yang berperan efektif yang selalu memberikan motivasi sebagai dorongan secara langsung untuk memberikan semangat dengan sesekali memberikan apresiasi pada pencapaian bawahan dengan memberikan ucapan selamat dan penghargaan, pujian serta pemberian penghargaan bagi karyawan yang mampu mencapai target. 
Pemimpin dari BPR Tish, BPR Ulati Dana Rahayu dan BPR Eka Ayu yang mendapatkan predikat sehat, juga turun langsung kelapangan ikut serta melakukan pemasaran sehingga dapat mengetahui kondisi yang terjadi saat ini, hal tersebutlah menjadikan karyawan terpacu untuk dapat menunjukan hasil kinerja yang baik, selain itu motivasi sebagai dorongan pribadi karyawan juga muncul untuk mendapatkan pengakuan dari rekan-rekan kerja dalam lingkungan organisasi serta perolehan reward yang sangat di dambakan oleh karyawan, hal itulah yang mendasari tercapainya target produktivitas karyawan yang ditemukan pada saat melakukan wawancara kepada karyawan bank. Herzberg dalam Carter (2006) menyatakan terdapat dua kebutuhan manusia yang berbeda yang dapat mempengaruhi motivasi. Pertama, kebutuhan fisiologis yang dapat dipenuhi dengan faktor higien seperti tempat berlindung atau bernaung. Kedua, kebutuhan psikologis untuk pencapaian dan pertumbuhan sebagai faktor motivator dimana Individu bersedia melaksanakan suatu pekerjaan jika individu tersebut terdorong untuk melakukan faktor yang menjadi pendorong. Anas (2010) menjelaskan bahwa motivasi berpengaruh positif signifikan terhadap kinerja. Penelitian Pujiyanti dan Isroah (2013) mengatakan bahwa semakin tinggi motivasi kerja, maka kinerja karyawan akan semakin meningkat.

Robbins \& Judge (2015:217) menyatakan kepemimpinan sebagai kemampuan yang dapat mempengaruhi suatu kelompok menuju pada pencapaian sebuah visi atau tujuan yang telah ditetapkan. Untuk sebuah perusahaan kepemimpinan merupakan faktor yang krusial, karena perusahaan membutuhkan nahkoda atau motor penggerak 
bagi anggotanya yang diharapkan akan berdampak baik bagi perusahaan ke arah yang lebih baik di setiap waktunya, salah satunya gaya kepemimpinan yang dibutuhkan untuk mencapai visi atau tujuan perusahaan sebagai pengerak bawahannya untuk melaksanakan pekerjaanya (Syaid, 2014).

Fenomena menyangkut masalah kepemimpinan yang terjadi dengan hasil wawancara karyawan dari BPR Tish, BPR Ulati Dana Rahayu, BPR Eka Ayu, BPR Suandana, BPR Sadhu Artha, BPR Artha Bali Jaya sebagai sampel awal terlihat peran seorang pemimpin yang tidak optimal dalam memberikan arahan, contohnya pimpinan hanya bisa memberikan pengarahan pada saat metting evalusi pencapain target, tanpa memberikan dorongan dan masukan baik secara langsung ataupun tidak langsung, keluhan ini langsung disampaikan oleh karyawan pada saat melakukan wawancara langsung keperusahaan, sehingga dalam hal ini BPR masih dihadapkan pada permasalahan peran kepemimpinan dalam menjalankan perusahaan.

Faktor lain yang juga dapat mempengaruhi kinerja karyawan adalah motivasi kerja karyawan. Robbins \& Judge (2015:117) mendefinisikan motivasi sebagai proses yang ikut menentukan intensitas, arah, dan ketekunan individu dalam usaha mencapai sasaran. Motivasi sebagai proses yang bermula dari kekuatan dalam hal fisiologis dan psikologis atau kebutuhan yang mengakibatkan perilaku atau dorongan yang ditujukan pada sebuah tujuan atau insentif (Mangkunegara, 2007:51). Melalui hasil observasi pada BPR yang berada di Kecamatan Sukawati Kabupaten Gianyar ditemukan indikasi rendahnya motivasi kerja. Dimana Motivasi yang rendah dilihat dari pencapaian target produktivitas yang belum dapat dicapai oleh karyawan pada 
BPR Suandana, BPR Sadhu Arta dan BPR Artha Bali Jaya, dari ketiga BPR tersebut pencapaian paling tinggi yaitu pada BPR Suandana yaitu di angka 65 persen, namun demikian angka tersebut belum dapat membuat BPR Suandana tergolong dengan predikat sehat, karena untuk mencapai predikat sehat harus dapat mencapai angka minimal 81 persen dilihat dari pelaporan produktivitas tingkat pencapian target karyawan BPR di Sukawati Gianyar, menyebabkan karyawan tidak memiliki gairah bekerja.

Perilaku-perilaku yang tidak efektif menyangkut peran kepemimpinan dan motivasi merupakan tindakan yang tidak mendukung efektivitas dan efisiensi dalam bekerja. Jika keadaan ini dibiarkan terus-menerus tanpa adanya perubahan yang dilakukan, akan berdampak pada menurunnya efektivitas dan produktivitas BPR seKecamatan Sukawati di Kabupaten Gianyar. Perlu adanya peran dari pimpinan, karyawan dan seluruh anggota perusahaan menjalin kinerja yang efektif serta adanya motivasi dalam melaksanakan pekerjaanya. Atas pertimbangan tersebut peneliti mengangkat tema "pengaruh kepemimpinan terhadap kinerja karyawan dengan motivasi kerja sebagai variabel moderasi di BPR (Bank Perkreditan Rakyat) seKecamatan Sukawati Gianyar.

Melalui pemaparan masalah yang telah dijabarkan, didukung dengan karya ilmiah dan teori tujuan dari karya ilmiah ini yang hendak dicapai 1) Bagaimanakah pengaruh kepemimpinan terhadap kinerja karyawan pada BPR se-Kecamatan Sukawati Kabupaten Gianyar, 2) Bagaimanakah pengaruh motivasi terhadap kinerja 
karyawan pada BPR se-Kecamatan Sukawati Kabupaten Gianyar, 3) Bagaimanakah peran motivasi dalam memoderasi pengaruh kepemimpinan terhadap kinerja karyawan pada BPR se-Kecamatan Sukawati Kabupaten Gianyar.

Kinerja Karyawan

Mangkunegara (2007:112) menyatakan, kinerja karyawan (prestasi kerja) adalah hasil kerja secara kualitas dan kuantitas yang dicapai oleh seseorang karyawan dalam melaksanakan tugasnya sesuai dengan tanggung jawab yang diberikan kepadanya, sedangkan. Handoko (2008:231) menyatakan kinerja sebagai suatu catatan perolehan yang dihasilkan dari fungsi suatu pekerjaan dan kegiatan selama suatu periode waktu tertentu. Berdasarkan uraian diatas dapat disimpulkan bahwa kinerja merupakan suatu hasil yang dikerjakan atau dibebankan kepada seseorang. Beban tersebut termasuk: tugas-tugas dibebankan berdasarkan kecakapan, pengalaman, kesungguhan, waktu sesuai dengan wewenang dan tanggung jawab masing-masing dalam memenuhi target atau sasaran yang telah ditentukan.

Kegunaan Penilaian Kinerja

Handoko (2008:219), menyatakan bahwa penilaian kinerja karyawan antara lain dapat dipergunakan untuk: Perbaikan kinerja (kinerja karyawan), penyesuaianpenyesuaian komnpensasi, yaitu merupakan masukan bagi manajemen untuk mengadakan evaluasi terhadap karyawan yang layak mendapatkan peningkatan penghasilan dan penghargaan. Keputusan-keputusan penempatan, yaitu sebagai masukan bagi manajemen untuk melakukan mutasi, rotasi ataupun promosi, 
kebutuhan latihan dan pengembangan kinerja yang kurang sesuai menunjukkan kebutuhan latihan.

Indikator Kinerja Karyawan

Cardoso Gomes ( 1995 : 142) dalam Dewi et al. (2014) mengatakan kinerja adalah catatan hasil produksi pada fungsi pekerjaan yang spesifik atau aktivitas selama periode waktu tertentu, yang terdiri dari: Quantity of work, Quality of work, Job knowledge, Creativeness, Cooperation, Depandability, Initiative, dan Personal Quality.

Kepemimpinan

Kepemimpinan berasal dari kata "to lead" yang berarti memimpin atau menunjukkan, sedangkan "leader" adalah pemimpin atau orang yang menunjukkan jalan, dapat pula berarti mengepalai suatu pekerjaan (Andrew, 2014). Henry Pratt Fairchil dalam Kartini Kartono (2003:39) mengandung pengertian yang luas yaitu seseorang yang memimpin dengan jalan memprakarsai tingkah laku sosial dengan mengatur, mengarahkan, mengorganisir atau mengontrol usaha/upaya orang lain, atau melalui prestise, kekuasaan atau posisi.

Indikator Kepemimpinan

Robbins dan Judge (2015:473) mengungkapkan adapun indikatorindikatornya sebagai berikut: integritas (integrity), merupakan salah satu atribut terpenting/kunci yang harus dimiliki seorang pemimpin berkaitan dengan konsistensi dalam tindakan-tindakan serta nilai-nilai visi yang ingin dicapai untuk perusahaan. 
Kompeten (competency), adalah ketrampilan yang diperlukan seorang pemimpin yang ditunjukkan oleh kemampuannya dengan konsisten memberikan tingkat kinerja yang tinggi dalam suatu fungsi sebagai seorang pimpinan. Konsistensi (consistency), artinya ketetapan serta kemantapan dalam bertindak mengenai kebijakan yang mencerminkan suatu konsistensi dalam menghadapi permasalahan yang sedang dialami perusahaan Loyal (loyality), artinya mutu dari sikap setia (loyal) dengan tindakan memberi atau menunjukkan dukungan dan kepatuhan yang teguh dan konstan seorang pimpinan kepada bawahannya. Terbuka (openess), artinya keterbukaan pemimpin dengan bawahan dalam menerima masukan, saran dalam mengambil keputusan sehingga tercipta hubungan kerjasama yang baik.

Motivasi

Sedarmayanti (2010:233) menyatakan motivasi merupakan kesediaan mengeluarkan tingkat upaya tinggi ke arah tujuan organisasi yang dikondisikan oleh kemampuan upaya itu untuk memenuhi kebutuhan individual. Sedangkan Robbins dan Judge (2015:56) menyatakan motivasi adalah proses yang berperan pada intensitas, arah dan lamanya berlangsung upaya individu ke arah pencapaian sasaran. Indikator Motivasi

Terdapat beberapa indikator dari motivasi menurut Sedarmayanti (2010:233239) yaitu antara lain sebagai berikut: gaji (salary), supervisi yang efektif, kebijakan administrasi, hubungan kerja yang harmonis, kondisi kerja yang nyaman, pekerjaan itu sendiri, peluang untuk maju (advance), pengakuan atau penghargaan (recognition), keberhasilan (achievement) dan tanggung jawab sebagai kewajiban 
seseorang untuk melaksanakan fungsi-fungsi yang ditugaskan dengan sebaik-baiknya sesuai dengan pengarahan yang diterima.

Teori Herzberg's

Adapun teori pendukung yang digunakan dalam penelitian ini ialah teori tentang kepuasan kerja yang disebut dengan Two factor theory (teori dua faktor) dari Herzberg's (2008). Menurut Rivai (2006:857) teori ini terdiri dari dua kelompok yaitu:

Satisfies ialah faktor-faktor atau situasi yang dibutuhkan sebagai sumber kepuasan kerja yang terdiri dari: pekerjaan yang menarik, penuh tantangan, ada kesempatan untuk berprestasi, kesempatan memperoleh penghargaan dan promosi. Terpenuhinya faktor tersebut akan menimbulkan kepuasan, namun tidak terpenuhinya faktor ini tidak selalu mengakibatkan ketidakpuasan. Dissatisfies (hygiene factors) ialah faktor-faktor yang menjadi sumber ketidakpuasan, yang terdiri dari: gaji/upah, pengawasan pimpinan, hubungan antarpribadi, kondisi kerja dan status motivasi.

Kerangka Konseptual

Kinerja merupakan hasil dari prestasi kerja (output) baik kualitas maupun kuantitas yang dicapai SDM persatuan periode waktu dalam melaksanakan tugasnya (Mangkunegara, 2007). Cardoso Gomes (1995:142) dalam Dudung dan Reni (2012) mengatakan kinerja diukur melalui dimensi: quantity of work, quality of work, job knowledge, creativeness, cooperation, depandability, initiative, dan personal quality. Luthans (2006:119) menyatakan dasar kepribadian untuk meningkatkan kinerja 
adalah peran kepemimpinan. Penelitian Chandra dalam Dudung dan Reni (2012) menyajikan karakteristik utama seorang pemimpin dalam menghadapi tantangan dan peluang bisnis pada abad 21 diukur melalui integritas (integrity), kompeten (competency), konsistensi (consistency), loyal (loyality) dan terbuka (openess). Pinar (2010) menyatakan motivasi dalam bekerja sangat diperlukan oleh seseorang dalam usaha meningkatkan kinerjanya. Motivasi seseorang melakukan suatu pekerjaan karena adanya suatu kebutuhan hidup yang harus dipenuhi. Penelitian Sedarmayanti (2010) dalam Noack (2011) motivasi diukur melalui dimensi gaji (salary), supervise, kebijakan administrasi, hubungan kerja, kondisi kerja, pekerjaan itu sendiri, peluang untuk maju, pengakuan atau penghargaan (recognition), keberhasilan (achievement), dan tanggung jawab. Berdasarkan latar belakang permasalahan dan landasan teoritis maka kerangka konseptual dari penelitian ini dapat dilihat pada Gambar 1.

\section{Gambar 1 Kerangka Konseptual Penelitian}

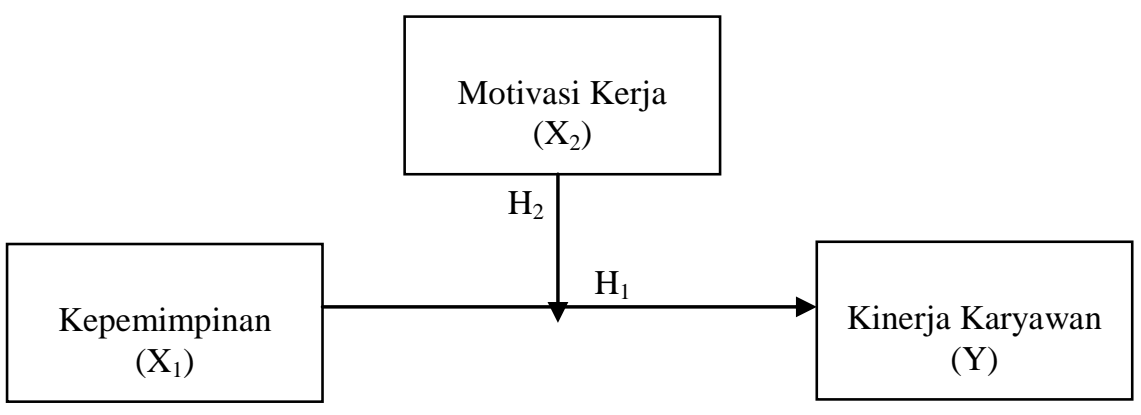

Sumber: konsep yang dikembangkan dalam penelitian ini, 2017

Kepemimpinan adalah kemampuan pemimpin untuk menciptakan dan mengartikulasikan suatu visi yang realistik, dapat dipercaya, atraktif tentang masa depan bagi suatu organisasi atau unit organisasional yang terus bertumbuh dan 
meningkat sampai saat ini (Robbins, 2006:195). Penelitian Ahmad (2014) menyatakan kepemimpinan memiliki hubungan positif terhadap peningkatan kinerja karyawan. Hal yang sama dikatakan oleh Dudung dan Reni (2012) kepemimpinan mampu memberikan dorongan dan berpengaruh positif terhadap peningkatan kinerja karyawan. Warsidi (2011) menyatakan, kepemimpinan berpengaruh positif dan signifikan terhadap kinerja pegawai. Berdasarkan pemahaman tersebut dapat dirumuskan hipotesis pertama sebagai berikut.

$\mathrm{H}_{1}$ : kepemimpinan memiliki pengaruh positif terhadap kinerja karyawan

Motivasi merupakan sebuah keahlian dalam mengarahkan karyawan pada tujuan organisasi agar mau bekerja dan berusaha sehingga keinginan para karyawan dan tujuan organisasi dapat tercapai (Noack, 2011). Beberapa peneliti telah menguji hubungan positif antara motivasi dengan kinerja karyawan, antara lain Idah and Jacob (2014). Pengaruh motivasi kerja terhadap kinerja menunjukan hasil yang sama bahwa hubungan antara kepemimpinan dengan kinerja karyawan menunjukan hubungan positif (Sahat, 2013). Dudung dan Reni (2012) menyatakan motivasi memiliki hubungan positif dalam meningkatkan kinerja karyawan. Berdasarkan pemahaman tersebut dapat dirumuskan hipotesis kedua sebagai berikut.

$\mathrm{H}_{2}$ : motivasi kerja memiliki pengaruh positif terhadap kinerja karyawan Motivasi adalah suatu proses yang menghasilkan suatu intensitas, arah, dan ketekunan individual dalam usaha untuk mencapai suatu tujuan (Robbins, 2006:81). Beberapa peneliti telah menguji hubungan antara motivasi dengan kinerja karyawan, 
antara lain Idah and Jacob (2014). Pengaruh motivasi kerja memperkuat hubungan antara kepemimpinan dengan kinerja karyawan secara positif dan signifikan (Sahat, 2013). Muttaqijn (2015) membuktikan motivasi memperkuat hubungan kepemimpinan terhadap peningkatan kinerja karyawan. Berdasarkan pemahaman tersebut dapat dirumuskan hipotesis pertama sebagai berikut.

$\mathrm{H}_{3}$ : motivasi kerja memperkuat pengaruh positif kepemimpinan terhadap kinerja karyawan

\section{METODE PENELITIAN}

Karya ilmiah ini menggunakan metode asosiatif yang bertujuan untuk mengetahui pengaruh ataupun juga hubungan antara dua variabel atau lebih (Sugiyono, 2013:56). dilakukan di pada PT BPR se-Kecamatan Sukawati Gianyar. Sedangkan ruang lingkup penelitian adalah pengaruh kepemimpinan terhadap motivasi kerja dan kinerja karyawan. Adapun alasan yang melatarbelakangi penelitian ini pada pada PT BPR se-Kecamatan Sukawati Gianyar yang merupakan usaha yang bergerak dibidang jasa keuangan, harus mampu memberikan jaminan atas kualitas layanan kepada nasabah dalam menunjang kelancaran dan kenyamanan dari proses pelayanan perbankan, perlu didukung kemampuan interpersonal karyawan yang produktif dan memiliki kinerja secara efektif, dengan dukungan dari peran seorang pemimpin dalam memberikan arahan, masukan serta motivasi di dalam bekerja.

Obyek penelitian adalah suatu hal atau apa saja yang menjadi perhatian dan apa saja yang diteliti (kamus bahasa Indonesia, 2008). Sebagai obyek dalam penelitian 
adalah kinerja karyawan. Subyek penelitian ini adalah seluruh karyawan yang bekerja di PT BPR se-Kecamatan Sukawati Gianyar. Variabel bebas adalah kepemimpinan $(\mathrm{X})$, motivasi (M) variabel dan variabel terikat adalah komitmen organisasi (Y).

Jenis data kuantitatif dan kualitatif yang dipergunakan seperti data jumlah karyawan, jawaban responden terhadap kuisioner dan seperti sejarah perusahaan, struktur organisasi dan aktivitas perusahaan. Sumber data primer dan sekunder yang dipergunakan seperti observasi dan pemberian kuesioner kepada responden dan sejarah berdirinya perusahaan, struktur organisasi perusahaan, dan jumlah karyawan.

Jumlah sampel adalah karyawan di PT BPR se-Kecamatan Sukawati Gianyar sebanyak 68 orang yang di klasifikasikan berdasarkan metode proportionate random sampling (Riduwan dan Sunarto, 2007:17). Data yang dikumpulkan dalam penelitian ini menggunakan metode observasi, pustaka dan kuesioner yang diberikan kepada responden yang telah dipilih.

Pengujian Instrumen Penelitian

Tabel 2 Hasil Uji Validitas

\begin{tabular}{cllcc}
\hline No & Variabel & Indikator & Korelasi & Keterangan \\
\hline 1 & Kepemimpinan $\left(\mathrm{X}_{1}\right)$ & $\mathrm{X} 1.1$ & 0,759 & Valid \\
& & $\mathrm{X} 1.2$ & 0,740 & Valid \\
& & $\mathrm{X} 1.3$ & 0,824 & Valid \\
& & $\mathrm{X} 1.4$ & 0,868 & Valid \\
& & $\mathrm{X} 1.5$ & 0,868 & Valid \\
2 & Motivasi Kerja $\left(\mathrm{X}_{2}\right)$ & $\mathrm{X} 2.1$ & 0,796 & Valid \\
& & $\mathrm{X} 2.2$ & 0,810 & Valid \\
& $\mathrm{X} 2.3$ & 0,828 & Valid \\
& $\mathrm{X} 2.4$ & 0,732 & Valid \\
& & $\mathrm{X} 2.5$ & 0,796 & Valid \\
& $\mathrm{X} 2.6$ & 0,810 & Valid \\
& $\mathrm{X} 2.7$ & 0,828 & Valid \\
& $\mathrm{X} 2.8$ & 0,732 & Valid \\
& $\mathrm{X} 2.9$ & 0,828 & Valid \\
\hline
\end{tabular}


ISSN : 2337-3067

E-Jurnal Ekonomi dan Bisnis Universitas Udayana 7.4 (2018):1107-1134

\begin{tabular}{llll}
\hline 3 Kinerja Karyawan (Y) & X2.10 & 0,732 & Valid \\
& Y.1 & 0,794 & Valid \\
& Y.2 & 0,568 & Valid \\
Y.3 & 0,739 & Valid \\
& Y.4 & 0,734 & Valid \\
Y.5 & 0,699 & Valid \\
Y.6 & 0,739 & Valid \\
& Y.7 & 0,734 & Valid \\
& Y.8 & 0,699 & Valid \\
\hline
\end{tabular}

Sumber : data diolah, 2017

Tabel 2. dapat dijelaskan bahwa masih-masing indikator variabel memiliki nilai person correlation lebih besar dari 0,30 , maka ini berarti indikator/pertanyaan yang digunakan layak digunakan untuk mengukur apa yang seharusnya diukur, dan dapat mengungkap data dari variabel yang diteliti secara tepat.

Tabel 3

Hasil Uji Reliabilitas

\begin{tabular}{clcc}
\hline \multirow{2}{*}{ No } & \multicolumn{1}{c}{ Variabel } & $\begin{array}{c}\text { Cronbach's } \\
\text { Alpha }\end{array}$ & Keterangan \\
\hline 1 & Kepemimpinan $\left(\mathrm{X}_{1}\right)$ & 0,811 & Reliabel \\
2 & Motivasi Kerja $\left(\mathrm{X}_{2}\right)$ & 0,801 & Reliabel \\
3 & Kinerja Karyawan $(\mathrm{Y})$ & 0,738 & Reliabel \\
\hline Sumber : data diolah, 2017 & &
\end{tabular}

Sumber : data diolah, 2017

Tabel 3 di atas dijelaskan bahwa nilai Cronbach's Alpha untuk masingmasing variabel $>0,6$, ini berarti alat ukur tersebut akan memberikan hasil yang konsisten untuk meneliti obyek yang sama.

Teknik analisis data yang diterapkan dalam penelitian ini dilakukan secara kuantitatif dengan menggunakan Moderating Regression Analysis. Moderating Regression Analysis dinyatakan dalam bentuk regresi berganda dengan persamaan mirip regressi polynomial yang menggambarkan pengaruh nonlinier (Ghozali, 2011:47) melalui model persamaan.

$$
\mathrm{Y}=\alpha+\beta_{1} \mathrm{X}_{1}+\beta_{2} \mathrm{X}_{2}+\left|\beta_{3} \mathrm{X}_{1} \mathrm{X}_{2}\right|+e
$$


Keterangan:

$\mathrm{Y} \quad=$ Kinerja karyawan

$\alpha \quad=$ Konstanta

$\beta_{1}-\beta_{3}=$ Koefisien

$\mathrm{X}_{1} \quad$ = Kepemimpinan

$\mathrm{X}_{2} \quad$ = Motivasi kerja

e $=$ Error

\section{HASIL DAN PEMBAHASAN}

\section{Analisis Faktor Konfirmatori}

Analisis faktor konfirmatori digunakan untuk menguji apakah indikator betulbetul merupakan indikator suatu variabel. Adapun tahapan analisis faktor konfirmatori adalah sebagai.

\section{Tabel 4 Koefisien Korelation Matriks Variabel}

\begin{tabular}{clcc}
\hline No & \multicolumn{1}{c}{ Variabel } & Chi-square & Sig \\
\hline 1 & Kepemimpinan $\left(\mathrm{X}_{1}\right)$ & 129,578 & 0,000 \\
2 & Motivasi Kerja $\left(\mathrm{X}_{2}\right)$ & 490,415 & 0,000 \\
3 & Kinerja Karyawan $(\mathrm{Y})$ & 408,535 & 0,000 \\
\hline Sumber : data diolah, 2017 & &
\end{tabular}

Tabel 13 menunjukkan bahwa nilai Chi-square untuk masing-masing variabel dengan nilai signifikansi dibawah 0,05 , maka ini berarti masingmasing item pada instrument memiliki nilai korelasi yang kuat sehingga layak dipergunakan dalam analisis faktor.

Tabel 5 Uji Kaiser Mayer Olkin (KMO)

\begin{tabular}{clcc}
\hline No & \multicolumn{1}{c}{ Variabel } & KMO & Ket. \\
\hline 1 & Kepemimpinan $\left(\mathrm{X}_{1}\right)$ & 0,783 & Valid \\
2 & Motivasi Kerja $\left(\mathrm{X}_{2}\right)$ & 0,912 & Valid \\
3 & Kinerja Karyawan $(\mathrm{Y})$ & 0,884 & Valid \\
\hline
\end{tabular}

Sumber : data diolah, 2017 
ISSN : 2337-3067

E-Jurnal Ekonomi dan Bisnis Universitas Udayana 7.4 (2018):1107-1134

Berdasarkan Tabel 5 menunjukkan bahwa nilai Kaiser Mayer Olkin (KMO) untuk masing-masing variabel lebih besar dari 0,5. Ini berarti masingmasing variabel memiliki kecukupan sampel untuk melakukan analisis faktor.

Tabel 6 Analisis Measure of Sampling Adequacy (MSA)

\begin{tabular}{|c|c|c|c|}
\hline No & Variabel & $\begin{array}{c}\text { Item } \\
\text { Pernyataan }\end{array}$ & Nilai MSA \\
\hline \multirow[t]{5}{*}{1} & Kepemimpinan $\left(\mathrm{X}_{1}\right)$ & $\mathrm{X} 1.1$ & 0,792 \\
\hline & & $\mathrm{X} 1.2$ & 0,752 \\
\hline & & $\mathrm{X} 1.3$ & 0,763 \\
\hline & & $\mathrm{X} 1.4$ & 0,853 \\
\hline & & $\mathrm{X} 1.5$ & 0,765 \\
\hline \multirow[t]{10}{*}{2} & Motivasi Kerja $\left(\mathrm{X}_{2}\right)$ & $\mathrm{X} 2.1$ & 0,913 \\
\hline & & $\mathrm{X} 2.2$ & 0,885 \\
\hline & & $\mathrm{X} 2.3$ & 0,938 \\
\hline & & X2.4 & 0,881 \\
\hline & & $\mathrm{X} 2.5$ & 0,911 \\
\hline & & X2.6 & 0,895 \\
\hline & & $\mathrm{X} 2.7$ & 0,929 \\
\hline & & $\mathrm{X} 2.8$ & 0,893 \\
\hline & & X2.9 & 0,950 \\
\hline & & $\mathrm{X} 2.10$ & 0,934 \\
\hline \multirow[t]{8}{*}{3} & Kinerja Karyawan (Y) & Y.1 & 0,910 \\
\hline & & Y.2 & 0,898 \\
\hline & & Y.3 & 0,854 \\
\hline & & Y.4 & 0,868 \\
\hline & & Y.5 & 0,861 \\
\hline & & Y.6 & 0,891 \\
\hline & & Y.7 & 0,927 \\
\hline & & Y.8 & 0,869 \\
\hline
\end{tabular}

Sumber : data diolah, 2017

Tabel 6 menunjukkan nilai MSA untuk masing-masing indikator variabel lebih besar dari 0,5, maka ini berarti model yang digunakan layak dipergunakan dalam model analisis faktor.

Tabel 7 Nilai Eigen Value

\begin{tabular}{cccc}
\hline No & Variabel & $\begin{array}{c}\text { Eigen } \\
\text { Value }\end{array}$ & $\begin{array}{c}\text { Cumulative } \\
\text { Variance } \\
\text { (persent) }\end{array}$ \\
\hline 1 & Kepemimpinan $\left(\mathrm{X}_{1}\right)$ & 3,075 & 61,449 \\
\hline
\end{tabular}




\begin{tabular}{clll}
\hline 2 & Motivasi Kerja $\left(\mathrm{X}_{2}\right)$ & 6,542 & 65,418 \\
3 & Kinerja Karyawan $(\mathrm{Y})$ & 5,520 & 68,998 \\
\hline
\end{tabular}

Sumber : data diolah, 2017

Berdasarkan Tabel 7 menunjukkan nilai eigen value dan masingmasing variabel lebih besar dari 1 , dan nilai percentage of variance lebih besar dari 5 persen, sehingga layak dipergunakan dalam model.

Tabel 8 Nilai Loading Faktor

\begin{tabular}{|c|c|c|c|c|}
\hline No & Variabel & Indikator & $\begin{array}{c}\text { Loading } \\
\text { Faktor }\end{array}$ & Ket. \\
\hline \multirow[t]{5}{*}{1} & Kepemimpinan & $\mathrm{X} 1.1$ & 0,824 & Valid \\
\hline & $\left(\mathrm{X}_{1}\right)$ & $\mathrm{X} 1.2$ & 0,804 & Valid \\
\hline & & $\mathrm{X} 1.3$ & 0,761 & Valid \\
\hline & & $\mathrm{X} 1.4$ & 0,774 & Valid \\
\hline & & $\mathrm{X} 1.5$ & 0,756 & Valid \\
\hline \multirow[t]{10}{*}{2} & Motivasi Kerja & $\mathrm{X} 2.1$ & 0,822 & Valid \\
\hline & $\left(X_{2}\right)$ & $\mathrm{X} 2.2$ & 0,837 & Valid \\
\hline & & $\mathrm{X} 2.3$ & 0,794 & Valid \\
\hline & & $\mathrm{X} 2.4$ & 0,786 & Valid \\
\hline & & $X 2.5$ & 0,821 & Valid \\
\hline & & $\mathrm{X} 2.6$ & 0,811 & Valid \\
\hline & & $\mathrm{X} 2.7$ & 0,828 & Valid \\
\hline & & $\mathrm{X} 2.8$ & 0,775 & Valid \\
\hline & & $\mathrm{X} 2.9$ & 0,835 & Valid \\
\hline & & $\mathrm{X} 2.10$ & 0,777 & Valid \\
\hline \multirow[t]{8}{*}{3} & Kinerja Karyawan & Y.1 & 0,825 & Valid \\
\hline & $(\mathrm{Y})$ & Y.2 & 0,814 & Valid \\
\hline & & Y.3 & 0,825 & Valid \\
\hline & & Y.4 & 0,817 & Valid \\
\hline & & Y.5 & 0,841 & Valid \\
\hline & & Y.6 & 0,830 & Valid \\
\hline & & Y.7 & 0,856 & Valid \\
\hline & & Y.8 & 0,837 & Valid \\
\hline
\end{tabular}

Sumber : data diolah, 2017

Tabel 8 menunjukkan bahwa nilai rotasi instrumen untuk masing-masing variabel lebih besar dari 0,4 maka ini berarti seluruh instrument dari masing-masing variabel telah memenuhi syarat dan menunjukkan korelasi yang kuat.

Analisis Regresi Moderasi 
Perhitungan analisis Moderating Regression Analysis dengan bantuan program Statistical Package of Social Science (SPSS) dengan hasil sebagai berikut.

Tabel 9 Hasil Pelaporan Analisis MRA

\begin{tabular}{ccccc}
\hline Model & \multicolumn{3}{c}{ Nilai } \\
\hline Y & $-0,208+0,569 \mathrm{ZX}_{1}+0,339 \mathrm{ZX}_{2}+0,366\left|\mathrm{ZX}_{1}-\mathrm{ZX}_{2}\right|$ \\
Std. Error & 0,107 & 0,135 & 0,124 & 0,101 \\
$\mathrm{t}$ & $-1,193$ & 4,216 & 2,729 & 2,630 \\
Sig. $\mathrm{t}$ & 0,058 & 0,000 & 0,008 & 0,011 \\
R Square & 0,655 & & & \\
F Hitung & 40,587 & & \\
Signifikansi F & 0,000 & & \\
Sumber : data diolah, 2017
\end{tabular}

Persamaan regresi pada Tabel 9. dapat dijelaskan untuk setiap variabel hal hal sebagai berikut: Nilai Koefisien $\beta_{1}$ yang diperoleh sebesar 0,569 menunjukan bahwa apabila kepemimpinan meningkatkan maka kinerja karyawan juga akan meningkat. Nilai Koefisien $\beta_{2}$ yang diperoleh sebesar 0,339 menunjukan bahwa apabila motivasi kerja meningkatkan maka kinerja karyawan juga akan meningkat. Nilai Koefisien $\beta_{3}$ yang diperoleh sebesar 0,366 menunjukan bahwa interaksi antara variabel kepemimpinan dan motivasi kerja bersifat positif. Artinya interaksi motivasi kerja memperkuat pengaruh kepemimpinan terhadap kinerja karyawan, dalam hal ini pemberian motivasi kepada bawahan untuk melaksanakan pekerjaan baik dari segi interistik dan ekstristik yang memberikan motif dari atasan kepada bawahan untuk meningkatkan kinerja karyawan.

\section{Uji Koefisien Determinasi $\left(\mathbf{R}^{2}\right)$}

Pengujian koefisien determinasi $\left(\mathrm{R}^{2}\right)$ berdasarkan Tabel 9 menunjukan bahwa nilai adjusted $\mathrm{R}$ square model 0,655 atau sebesar $65,5 \%$. Hasil ini memiliki arti 
sebesar 65,5\% variasi atau perubahan kinerja karyawan dapat dijelaskan oleh variasi variabel dalam model tersebut yaitu kepemimpinan dan motivasi kerja.

Pengujian Hipotesis

Analisis uji $\mathrm{F}$ memperlihatkan nilai $\mathrm{F}_{\text {hitung }}(40,587)>\mathrm{F}_{\text {tabel }}(3,14)$ dengan tingkat signifikan $0,000<0,05$ maka Ho ditolak Hi diterima. Hal ini berarti variabel kepemimpinan dan motivasi kerja dan variabel interaksi secara bersamaan berpengaruh signifikan terhadap kinerja karyawan pada BPR (Bank Perkreditan Rakyat) se-Kecamatan Sukawati Gianyar. Hal ini mengindikasikan bahwa model yang digunakan dalam penelitian ini layak dipergunakan.

Analisis Uji t

Berdasarkan hasil yang dijelaskan bahwa $t_{\text {hitung }}(4,216)>t_{\text {tabel }}(1,671)$ dengan tingkat signifikansi $(0,000)<\alpha(0,05)$, sehingga $\mathrm{H}_{0}$ ditolak dan $\mathrm{H}_{1}$ diterima yang berarti bahwa kepemimpinan secara parsial berpengaruh positif dan signifikan terhadap kinerja karyawan pada BPR (Bank Perkreditan Rakyat) se-Kecamatan Sukawati Gianyar.

Berdasarkan hasil yang dijelaskan bahwa $t_{\text {hitung }}(2,729)>t_{\text {tabel }}(1,671)$ dengan tingkat signifikansi $(0,008)<\alpha(0,05)$, sehingga $\mathrm{H}_{0}$ ditolak dan $\mathrm{H}_{1}$ diterima yang berarti bahwa motivasi secara parsial berpengaruh positif dan signifikan terhadap kinerja karyawan pada BPR (Bank Perkreditan Rakyat) se-Kecamatan Sukawati Gianyar. 
Berdasarkan hasil yang dijelaskan bahwa nilai koefisien regresi $\mid Z_{X_{1}-}$ $\mathrm{ZX}_{2} \mid$ atau variabel kepemimpinan dan motivasi kerja adalah sebesar 0,366 dengan tingkat signifikansi sebesar 0,011 lebih kecil dibandingkan dengan taraf nyata $\alpha=$ 0,05. Hal ini menunjukan bahwa motivasi kerja mampu memperkuat hubungan kepemimpinan dengan kinerja karyawan pada BPR (Bank Perkreditan Rakyat) seKecamatan Sukawati Gianyar.

Pembahasan Hasil Analisis Data

Hasil analisis data kepemimpinan memberikan pengaruh positif terhadap kinerja karyawan, terlihat adanya penerapan kepemimpinan yang baik pada pada BPR (Bank Perkreditan Rakyat) se-Kecamatan Sukawati Gianyar akan mampu meningkatkan kinerja karyawan. Hasil penelitian ini searah dengan pernyataan Warsidi (2011) menyatakan, kepemimpinan berpengaruh positif dan signifikan terhadap kinerja pegawai. Eunike and Pio1 (2015) menyatakan bahwa, kepemimpinan berpengaruh positif dan signifikan terhadap kinerja karyawan. Eunike dan Greis (2015) gaya kepemimpinan secara positif memberikan pengaruh terhadap kinerja karyawan.

Hasil analisis data menunjukkan motivasi kerja memberikan pengaruh positif terhadap kinerja karyawan, dengan adanya motivasi kerja sebagai pendorong bagi karyawan menunjukkan sikap dalam meningkatkan kinerjanya. Hasil penelitian ini searah dengan pernyataan Sahat (2013) yang membuktikan pengaruh motivasi kerja terhadap kinerja menunjukan hasil yang positif. Noack (2011) motivasi memiliki peran positif dalam meningkatkan kinerja karyawan. Dibuktikan oleh Andrew (2014) 
dalam penelitiannya menyatakan motivasi sebagai dorongan memiliki pengaruh positif dalam meningkatkan kinerja karyawan.

Berdasarkan hasil analisis data diketahui bahwa motivasi kerja memoderasi atau dapat memperkuat pengaruh kepemimpinan terhadap kinerja karyawan. Hal ini mengandung arti bahwa semakin baik motivasi kerja yang diberikan oleh pimpinan terhadap karyawan sepenuhnya dapat memberikan pengaruh atau memperkuat hubungan kepemimpinan pada kinerja karyawan. Hasil penelitian ini mendukung pernyataan Fadime \& Ayca (2012) menyatakan motivasi kerja memperkuat hubungan antara kepemimpinan dengan kinerja karyawan secara positif dan signifikan. Hal yang sama dinyatakan oleh Noack (2011) motivasi memperkuat hubungan positif kepemimpinan dalam meningkatkan kinerja karyawan. Dibuktikan oleh Andrew (2014) dalam penelitiannya menyatakan motivasi sebagai dorongan memiliki pengaruh positif dalam meningkatkan kinerja karyawan.

\section{SIMPULAN DAN SARAN}

Berdasarkan pada pembahasan pada bab-bab sebelumnya, maka adapun halhal yang dapat disimpulkan yaitu, kepemimpinan berpengaruh positif dan signifikan terhadap kinerja karyawan pada BPR se-Kecamatan Sukawati Kabupaten Gianyar. Motivasi kerja berpengaruh positif dan signifikan terhadap kinerja karyawan pada BPR se-Kecamatan Sukawati Kabupaten Gianyar. Motivasi kerja memoderasi pengaruh kepemimpinan terhadap kinerja karyawan pada BPR se-Kecamatan 
Sukawati Kabupaten Gianyar. Motivasi kerja memperkuat pengaruh kepemimpinan terhadap kinerja karyawan.

Berdasarkan simpulan, saran-saran yang dapat diberikan kepada BPR seKecamatan Sukawati Kabupaten Gianyar dalam menjalankan usahanya sebagai jasa dibidang perbankan seorang pemimpin harus bersikap konsisten antara apa yang diimani dan kelakukannya, antara sikap dan tindakkan, berfokus untuk mencapai tujuan perusahaan. Seorang Pemimpin yang memiliki integritas adalah yang memiliki etika dan moral dalam menjalankan kepemimpinannya. Pemimpin BPR seKecamatan Sukawati Kabupaten Gianyar dalam usaha meningkatkan kinerja harus memotivasi karyawan, seperti sikap tanggung jawab dan mengajarkan agar segala pekerjaan dikerjakan sesuai dengan petunjuk-petunjuk yang sudah diberlakukan perusahaan karena keseluruhan karyawan memiliki kewajiban dalam melaksanakan fungsi-fungsi yang sudah ditugaskan oleh perusahaan. Bagi peneliti selanjutnya diharapkan dapat mengembangkan penelitian ini, dengan saran dapat menambah variabel misalnya talent management, empowerment, turnover intention karyawan. Selain itu peneliti selanjutnya dapat melakukan pada industri perusahan yang berbeda, misalnya: hotel, restaurant, manufaktur, UMKM, dan lainnya.

\section{REFERENSI}

Ahmad Mappaenre, 2014. Kepemimpinan Visioner Kepala Sekolah, Kepemimpinan Diri Guru dan Sekolah Efektif. Jurnal Ilmu Administrasi Negara. 12(4): h: 217-288

Aan Agustina, Anisa Rosdiana, Dwi Dina Rahma V, 2013. Visionary Leadership Models to Increase Employee Morale Research in De' Risole Family's Café: 
JL.Citarum 24 Bandung West Java Indonesia. International Journal of Science and Research. 2(1): pp: 695-700

Andrew Achenbaum, W., 2014. Robert N. Butler, MD (January 21, 1927-July 4, 2010): Visionary Leader. Internationa Journal The Gerontologist. 54(1): pp: 7-12

Colette M Taylor, 2014. Visionary leadership and its relationship to organizational effectiveness. Journal Leadership \& Organization Development. 35(6): pp: 566-583

Dewi Puspariani, Ni Kadek., Dunia, I Ketut, Lulup Endah Tripalupi. 2014. Pengaruh Kompetensi Emosional dan Pengendalian Pekerjaan terhadap Kinerja Karyawan PD BPR Bank Buleleng 45 Singaraja. Jurnal Universitas Ganesha. 4(1): h: 1-10

Dhammika, K. A. S., 2014. Visionary Leadership and Organizational Citizenship Behavior: An Assessment of Impact of Sectarian Difference. Journal Global Business, Economics, Finance and Banking. 3(2): pp: 1-10

Douglas Archbald, Ph.D., 2013. Vision and Leadership: Problem-based Learning as a Teaching Tool. Journal of Leadership Education. 12(2): pp: 136-147

Dudung Juhana, Reni Ambarsari, 2012. Pengaruh Kepemimpinan Visioner dan Pengembangan Karier Terhadap Kepuasan Kerja serta Implikasinya pada Kinerja Pegawai Dinas Pertambangan dan Energi Provinsi Jawa Barat. Jurnal Ekonomi Bisnis \& Entrepreneurship. 6(1): h: 15-25

Eunike Anggie Pio, Greis Sendow. 2015. Pengaruh Gaya Kepemimpinan Visioner, Kompensasi dan Penempatan Kerja terhadap Kinerja Pegawai di Sekretariat Daerah Kabupaten Minahasa Tenggara. Jurnal EMBA. 3(3): h: 1140-1150

Fadime Cinar, Ayca Kaban. 2012. Conflict Management and Visionary Leadership: An Application in Hospital Organizations. Journal Social and Behavioral Sciences. 58 (2): pp: 197-206

Ferdinand, Augusty. 2006. Metode Penelitian Manajemen. Semarang: Badan Penerbitan Universitas Diponegoro

Fitria Anike Widyawati, Djum Noor Benty. 2014. Hubungan Kepemimpinan Visioner Kepala Sekolah dan Tingkat Kinerja Tenaga Kependidikan dengan Kualitas Sekolah di SMP Se-Kota Malang. Jurnal Ekonomi dan Bisnis. 1(4): h: 1-16

Frances Westley, Henry Mintzberg, 2014. Visionary Leadership and Strategic Management. Journal of Strategic Management. 10 (1): pp: 17-32 
Ghozali, Imam, 2011. Aplikasi Analisis Multivariate Dengan Program SPSS. Edisi Kedua.Semarang : Bagian Penerbit Universitas Diponogoro.

Handoko T. Hani. 2008. Manajemen Personalia dan Sumber Daya Manusia. Edisi 2, Yogyakarta : BPFE UGM.

Handoko, Hani T, dan Reksohadiprodjo Sukanto, 2009. Organisasi Perusahaan. EdisikeduaYogyakarta : BPFE

Herzberg, Fredrick. 2008. One More Time: How do You Motivate Employees?. Boston : Harvard Bussiness Press

Idah Naile and Jacob M Selesho, 2014. The Role of Leadership in Employee Motivation. Mediterranean Journal of Social Sciences. 5(3): pp: 175-182

Kamus Bahasa Indonesia. 2008. Jakarta, Balai Pustaka

Kartini, Kartono. 2003. Dasar-dasar Manajemen. Jakarta : Grasindo.

Kelly Rouse Riesenmy, 2008. The Moderating Role of Follower Identification in the Relationship Between Leader and Follower Visionary Leadership. Emerging Leadership Journeys. 1(2): pp: 62-77

Luthans, Fred. 2006. Organizational Behavior, Ninth Edition, McGraw Hill, Boston

Mangkunegara, A. A. Anwar Prabu. 2007. Manajemen Sumber Daya Manusia Perusahaan. Bandung: PT. Remaja Rosdakarya

Mathis, Robert L. dan John H. Jackson. 2009. Manajemen Sumber Daya Manusia. Edisi Kesepuluh. Alih Bahasa: Diana Angelica. Jakarta: Penerbit Salemba Empat.

Marudut Marpaung, 2014. Pengaruh Kepemimpinan dan Team Work terhadap Kinerja Karyawan di Koperasi Sekjen Kemdikbud Senayan Jakarta. Jurnal Ilmiah Widya. 2(1): h: 33-40

Muttaqijn, M. Imam., 2016. Pengaruh Kepemimpinan Visioner, Komunikasi Organisasi dan Kompetensi terhadap Kepuasan Kerja serta Implikasinya pada Kinerja Karyawan. Jurnal Kontigensi. 4(2): h: 136-144

Noack Pariaribo, 2011. Pengaruh Gaya Kepemimpinan dan Motivasi Kerja Terhadap Kepuasan Kerja Serta Dampaknya terhadap Kinerja Pegawai pada Badan 
Perencanaan Pembangunan Daerah di Kabupaten Supiori. Jurnal Ekonomi dan Bisnis. 4(3): h: 1-16

Obiwuru Timothy C, Okwu, Andy T., Akpa, Victoria O., Nwankwere, Idowu A., 2011. Effects of Leadership Style on Organizational Performance: A Survey of Selected Small Scale Enterprises in Ikosi-Ketu Council Development Area of Lagos State, Negeria. Australian Journal of Business and Management Research. 1(7): pp: 100-107

Raza Khan, Adeel Bukhari and Zahid Ali Channar, 2016. Effects of Leadership Style on Health Care Organizational Performance: A Survey of Selected Tertiary Care Hospital in Karachi, Pakistan. International Journal of Economics \& Management Sciences. International Journal Economic Management. 5(3): pp: 1-7

Riduwan dan Sunarto. 2007. Pengantar Statistika Untuk Penelitian Pendidikan, Sosial, Ekonomi, dan Bisnis. Bandung : Alfabeta.

Rivai, Veithzal. 2006. Kepemimpinan dan Perilaku Organisasi. Jakarta : PT. Raja Grapindo Persada

Robbins, Stephen P., 2006. Perilaku Organisasi, Jilid I, PT.Prenhallindo, Alih Bahasa: Hadyana Pujaatmaka, Jakarta

Robbins, S.P dan Timothy A. Judge. 2015. Perilaku Organisasi, Edisi 16. Jakarta: Salemba Empat

Sahat Simbolon, 2013. Pengaruh Kepemimpinan Visioner, Motivasi dan Kompetensi terhadap Budaya Kerja dan Komitmen serta Implikasinya pada Kinerja Dosen. Jurnal Kontingensi, 1(2): h: 78-88

Sugiyono. 2013. Metode Penelitian Kuantitatif Kualitatif dan R\&D. Bandung: Alfabeta.

Syaid Maulana, 2014. Peranan Kepemimpinan Visioner dan Budaya Organisasi dalam Membentuk Komitmen Karyawan di Universitas Komputer Indonesia.

Warsidi, 2015. Pengaruh Kepemimpinan Visioner dan Pemberdayaan Pengawai di Dinas Tata Ruang dan Permukinan Kabupaten Cianjur (Studi Terhadap Persepsi Pegawai di Lingkungan Distarkim Kab. Cianjur) 